\title{
Dynamism of viticultural systems in Mendoza (1988-2008)
}

\author{
M. Eugenia Van den Bosch ${ }^{1, a}$, Adriana Bocco², and M. Cecilia Ruiz ${ }^{3}$ \\ ${ }^{1}$ EEA Mendoza, INTA Mendoza, San Martìn 3853, M. Drummond, Mendoza República, Argentina \\ ${ }^{2}$ CONICET INTA, EEA Mendoza, San Martìn 3853, M. Drummond, Mendoza República, Argentina \\ ${ }^{3}$ Dirección de Estadísticas e Investigaciones Económicas, Gobierno de Mendoza República, Argentina
}

\begin{abstract}
Viticulture holdings of Mendoza Argentina, were classified by the allocation and the stratum size according to their total acreage based on the data of the last three National Agricultural Censuses (1988, 2002 and 2008). There are different behaviors in each stratum according to each growing zone. It has been observed that in all "oasis" smaller is the holding, higher is the rate of shrinkage. On the other hand the bigger sizes grow and the acreage concentration of these units has increased significantly. Behaviors were clustered according to their path: taking into account its relationship with both zonal and provincial level stratum averages. Areas like the Oasis Sur have suffered a major a regressive process that has involved almost all the strata. The Uco Valley has shown a significant dynamism in units of more than $25 \mathrm{ha}$, while the small holdings have moved back, but with lower rates than the average of these strata. The Oasis Norte has also been subject to a bipolar process where a significant loss of small vineyards with the rise of new big holdings. Oasis Este is the only one that remains with lower regression rates.
\end{abstract}

\section{Introduction}

The Province of Mendoza is the main wine production region of Argentina. Located in Cuyo region, "land of the sands", it has been inhabited since $1700 \mathrm{BC}$, according to various authors as Michieli [1] by a small tribe dedicated to fishing, growing vegetables and hunting, which along time was configured as the Huarpes. The foundation of the City of Mendoza in 1561 didn't have any goal of agricultural production, but for local supply. The Oasis Norte preserved pre-Columbian crops. The first vineyards from raisins seeds [2] were planted, also new parishes implanted grapevines from imported stakes. Over the years local production supplied not only Mendoza but surrounding provinces consumption.

During the $2^{\text {nd }}$ half of the $19^{\text {th }}$ Century the railroad arrived, thousands of European immigrants came to work, the system of collection and distribution of irrigation water was improved and new oasis were annexed [2].

The $20^{\text {th }}$ century was marked by cyclical processes of overproduction and shortage [3], reaching in 1980 an acreage of about 250 thousands ha. However, the following decade was signed by decay and abandonment [4].

New viticulture emerged during the nineties. Technological innovations were adopted and competition in land use, primarily from the urban sector, became evident. Like it happened in other countries, the number of vineyard farms decreased. The acreage has also been reduced but it was not at the same rate than the frequency. This fact led to suppose differential behaviors as a result of different

\footnotetext{
${ }^{a}$ Corresponding author: vandenbosch.maria@inta.gob.ar
}

vulnerabilities and capacities of response to changing factors.

The agrarian structure describes the configuration of an agro ecosystem. This configuration includes some attributes such as: land tenure [5,6], social organization [7-12], farming system [10,13,14], capitalization level $[7-9,11,15]$, within this criteria is the size of the holding $[11,12,15,16]$.

A spatial process is a change in system configuration toward a particular direction. The following may be present in this region: 1) Globalization expansion to primary activities [17-21], 2) The fragmentation of farms in units of smaller size, many with smallholder characteristics [22]. 3) Lack of generational change [23]. 4) Abandonment and rural exodus [24,25]. 5) Urban sprawl towards urban rural fringe [26-29]. 6) Polarization between capitalized companies and family farms [12]. 7) Expansion of the agricultural frontier to the edges of the oasis [30]. 8) Increased proletarian labor [31].

The persistence and growth of some of these units, assessed according to the size of the production unit planted acreage- are analyzed in this paper, under the assumption that these differences may confer adaptability, stability or resilience facing context switches during the passing of the years [32-34]. Several conceptual frameworks are available to study the dynamics of rural systems, but they often lack a clear description of the structural changes and a comprehensive analysis of system properties, which are key aspects of the resilience theory [35]. The need arises to focus over some variables, underlying many times, that can explain the ability to provide system recovery and survival [36]. Finding these

This is an Open Access article distributed under the terms of the Creative Commons Attribution License 4.0, which permits unrestricted use, distribution, and reproduction in any medium, provided the original work is properly cited. 
variables one may be able to recognize productive systems of differential persistence or growth capacity and then designing development strategies [37]. It is therefore essential to characterize these aspects.

This work is a part of a broader project that studies the structure of Mendoza agro ecosystem. The aim is to recognize the historical trajectory from 1988-2008 of vine growers of different strata and allocation, assessed by frequency and area share, under the assumption that the economic size of the holding, measured by the planted acreage is an explanatory factor of differential behaviors. This knowledge is useful for the assessment of sustainability parameters such as vulnerability, resilience, flexibility and stability, to be applied to prospective studies and the design of development strategies. Also, the general characterization of the dynamics allows the formulation of hypotheses of temporal and spatial processes to be addressed in specific strategies of further work.

\section{Materials \& methods}

\subsection{The Oasis of mendoza province}

Mendoza is located in the Central West Argentina; both human settlements and agro industrial activities are settled in anthropogenic oasis developed from glacial water. Each oasis is linked to a river basin, and it is considered an homogeneous agro economic zone: 1) Oasis Norte, the oldest, preexisting of Spanish conquest but developed after it during the $16^{\text {th }}$ century. It includes the Metropolitan Area of Mendoza City (AMM) and comprises the irrigated areas of the Departments of Luján de Cuyo, Maipú, Guaymallén, Las Heras and Lavalle. It is watered by the surface and groundwater basin of Rio Mendoza 2) Oasis Este, irrigated by the Lower Rio Tunuyán and partially by Rio Mendoza (Canal St. Martin); it historically was developed as an expansion of the Oasis Norte. Includes the Departments of San Martín, Junín, Rivadavia, Santa Rosa and La Paz. 3) Valle de Uco or Oasis Centro consists of the Departments of Tunuyán, Tupungato and San Carlos and it is irrigated by the Rio Tunuyán Superior and a profuse network of creeks. 4) Oasis Sur aroused late last century. It consists of the irrigated areas of the departments of San Rafael and General Alvear. Water resources are provided by Rios Diamante and Atuel (See Map 1). There are also two minor "oasis", one corresponding to the Malargüe River and the Valley of Uspallata in the Department of Las Heras.

\subsection{Viticulture systems}

The data was provided by the user bases of the last three National Agricultural Censuses (CNA) of the Province of Mendoza for the years 1988, 2002 and 2008. Agricultural Farm (EAP) is the unit of analysis, beyond the number of plots (non-contiguous land), each EAP has the same direction or management and the means of production and part of the labor used is the same. It is closer to the figure of the vine grower more than the plot or vineyard. For the purposes of this paper it is agreed that a farm is belonging to Viticulture System when the grapevine is the main crop

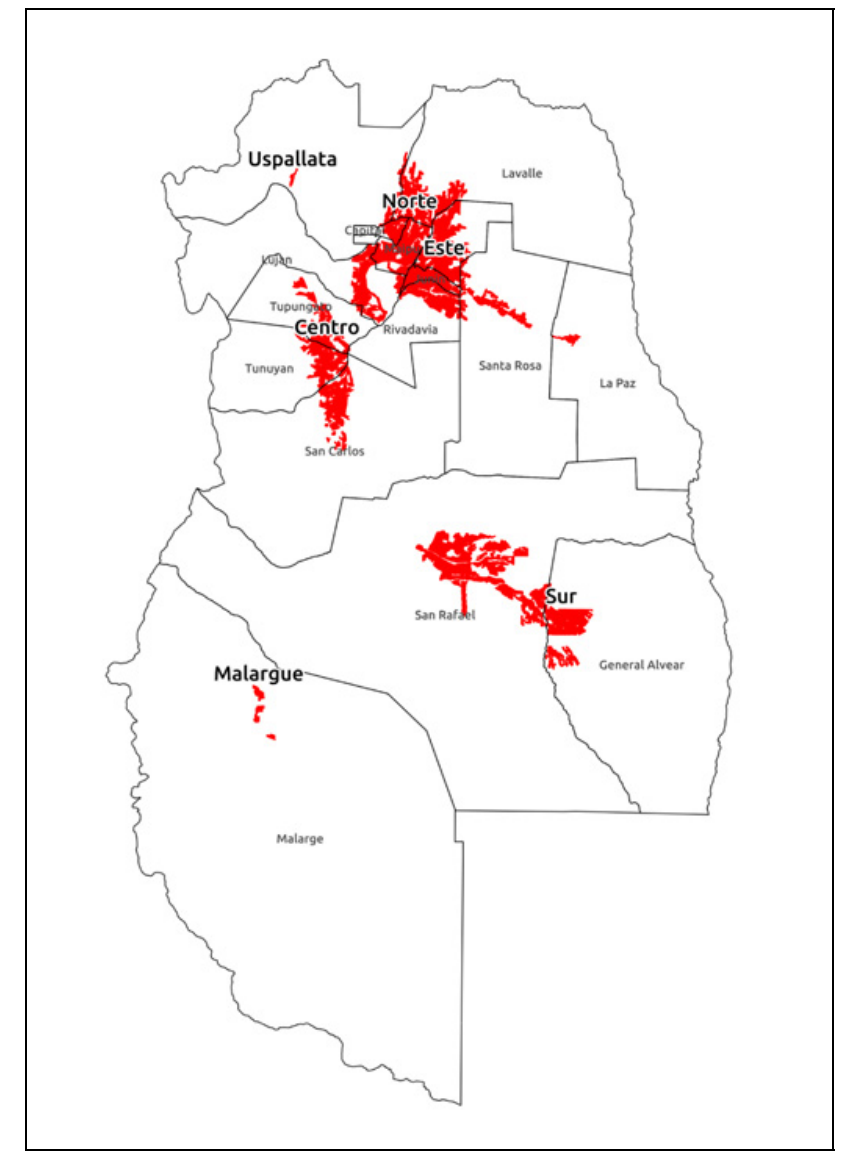

Mapa 1. Los Oasis de la Provincia de Mendoza.

(vineyards acreage is bigger than any other area used for other activities that may be present on the farm).

\subsection{Size strata}

The variable Total Area of the holding includes land of different uses and suitability, with and without water availability. The variable Planted Area is considered better indicator as it accurately reflects the economic dimension. The size strata evaluated were: Very Small (0-4,9 ha), Small (5 to 9.9 ha), Medium (10 to 24.9 ha), MediumLarge ( 25 to 49.9 ha), Large (50 to 99.9 ) ha and Very Large over 100 ha.

\subsection{Dynamics of farming systems}

The intercensal analysis is focused on two attributes: the frequency of EAP and the total planted area as an indicator of the spatial extent of the system. The change was established by comparing the growth or reduction rate of each strata and zone with the average rate of the provincial strata and zone. Table 1 describes the identified trajectory styles, based on the overall dynamics of the whole. In this way it was possible to detect those groups with different behaviors, when they were compared to the average, and this allowed suggesting that this attributes can determine evolutionary strengths or weaknesses. 
Table 1. Trajectories according to growth or decreasing rate.

\begin{tabular}{|l|l|l|}
\hline Trajectory & $\begin{array}{l}\text { Genera } \\
\text { Trajectory }\end{array}$ & $\begin{array}{l}\text { Group rate compared } \\
\text { with general }\end{array}$ \\
\hline Very Dynamic & Dynamic & $\begin{array}{l}\text { Growth rate higher } \\
\text { than general }\end{array}$ \\
\hline Dynamic & Dynamic & $\begin{array}{l}\text { Growth rate equal } \\
\text { than general }\end{array}$ \\
\hline Lesser Dynamic & Dynamic & $\begin{array}{l}\text { Growth rate lower } \\
\text { than general }\end{array}$ \\
\hline Stable & Stable & Stable \\
\hline $\begin{array}{l}\text { Lesser } \\
\text { Regressive }\end{array}$ & Regressive & $\begin{array}{l}\text { Decreasing rate lower } \\
\text { than general }\end{array}$ \\
\hline Regressive & Regressive & $\begin{array}{l}\text { Decreasing rate equal } \\
\text { than general }\end{array}$ \\
\hline $\begin{array}{l}\text { Very Regressive } \\
\text { Degressive }\end{array}$ & $\begin{array}{l}\text { Decreasing rate higher } \\
\text { than general }\end{array}$ \\
\hline $\begin{array}{l}\text { Dynamic } \\
\text { countercyclical } \\
\text { Regressive } \\
\text { countercyclical }\end{array}$ & Degressive & Growth rate \\
\hline
\end{tabular}

Table 2. Provincia of Mendoza. Intercensus evolution of Viticultural EAP by stratus (EAP).

\begin{tabular}{|l|r|r|r|}
\hline \multirow{2}{*}{ Stratus } & \multicolumn{3}{|c|}{ Viticulture EAP } \\
\cline { 2 - 4 } & 1988 & 2002 & 2008 \\
\hline Total & $\mathbf{1 5 . 2 6 7}$ & $\mathbf{1 0 . 2 0 5}$ & $\mathbf{8 . 5 4 9}$ \\
\hline Very Small & 7.930 & 4.593 & 3.495 \\
\hline Pequeñas & 3.415 & 2.286 & 1.872 \\
\hline Medium & 2.614 & 2.059 & 1.890 \\
\hline Medium Large & 815 & 786 & 742 \\
\hline Large & 348 & 337 & 371 \\
\hline Very Large & 145 & 144 & 179 \\
\hline
\end{tabular}

\subsection{Multivariate analysis of trajectories}

A data base for each case (stratus and oasis) was performed. The columns are the growth or decreasing rates calculated of the frequency and acreage, compared with zonal and stratum averaged rates. Then it was possible to cluster these trajectories using statistical multivariate analysis procedures, following the recommendations of Hair et al. [38]. From initial variables collinear ones were withdrawn using a correlation test. Then Principal Components were generated and the resulting axes were used for the final classification by cluster analysis using the Average Linkage method. This classification technique allows grouping data with multiple attributes such that the Euclidean distance is minimum within the cluster and maximum among clusters; so homogeneous and different groups were formed.

\section{Results}

\subsection{Evolution at provincial scale}

According to Table $256 \%$ of winegrowers recorded 20 years ago persist; the acreage reduction was not significant as it is held to 94\% (Table 3). These figures show that the disappearance is skewing toward smaller ones. The decreasing rates of Very Small and Small
Table 3. Provincia of Mendoza. Intercensus evolution of the planted area in Viticultural EAP by stratus (ha).

\begin{tabular}{|l|r|r|r|}
\hline \multirow{2}{*}{ Stratus } & \multicolumn{3}{|c|}{ Planted Area (ha) } \\
\cline { 2 - 4 } & 1988 & 2002 & 2008 \\
\hline Total & $\mathbf{1 6 6 . 6 2 3}$ & $\mathbf{1 3 8 . 0 5 4}$ & $\mathbf{1 3 9 . 9 0 3}$ \\
\hline Very Small & 19.032 & 11.855 & 9.166 \\
\hline Small & 25.558 & 17.445 & 14.309 \\
\hline Medium & 41.554 & 33.106 & 30.434 \\
\hline Medium Large & 28.400 & 27.542 & 26.259 \\
\hline Large & 23.988 & 23.226 & 25.535 \\
\hline Very Large & 28.091 & 24.881 & 34.198 \\
\hline
\end{tabular}

Table 4. Oasis Norte Provincia of Mendoza. Intercensus evolution of Viticultural EAP by stratus (EAP).

\begin{tabular}{|l|r|r|r|}
\hline \multirow{2}{*}{ Stratus } & \multicolumn{3}{|c|}{ Viticultural EAP } \\
\cline { 2 - 4 } & 1988 & 2002 & 2008 \\
\hline Total & $\mathbf{4 . 0 0 6}$ & $\mathbf{2 . 3 1 9}$ & $\mathbf{2 . 1 0 4}$ \\
\hline Very Small & 2.189 & 1.236 & 852 \\
\hline Small & 826 & 628 & 407 \\
\hline Medium & 650 & 332 & 467 \\
\hline Medium Large & 218 & 74 & 209 \\
\hline Large & 79 & 28 & 107 \\
\hline Very Large & 44 & 20 & 62 \\
\hline
\end{tabular}

holdings have a Very Regressive behavior when their frequency and acreage were compared with the provincial rate. The frequency rates of Medium ones behave Less Regressive but the acreage rate is Very Regressive. Medium Large rates are Less Regressive. On the other hand the Large and Very Large vineyards exposed a Dynamic Countercyclical behavior. The acreage involved by these two strata increased from $31 \%$ to $43 \%$ during this period.

\subsection{Evolution at oasis scale}

\subsubsection{Oasis Norte}

Only $53 \%$ of the EAP persists, following a similar pattern to provincial rates, with more severe retraction in strata from Very Small to Medium. On the other hand, the growth of Large and Very Large ones was higher than average highlighting a polarization process.

The total acreage was not as affected as frequency due to the expansion of the Large and Very Large ones, and it behaves as less recessive than provincial average. The retraction of the area of Very Small and Small was very Regressive, while in the Medium ones it was Less Regressive. Medium Large behave dynamic countercyclical. The concentration of the two biggest grew from $33 \%$ to $49 \%$.

\subsubsection{Oasis Este}

In this zone the amount reduced was less than the provincial average. The most acute reduction is observed also on Very Small farms (Table 6), the others expose a Less Regressive pace, while the Very Large ones show a Dynamic Countercyclical when they face the zonal averages. The reduction rates of all Medium Large are less 
Table 5. Oasis Norte Provincia of Mendoza. Intercensus evolution of the planted area in Viticultural EAP by stratus (ha).

\begin{tabular}{|l|r|r|r|}
\hline \multirow{2}{*}{ Stratus } & \multicolumn{3}{|c|}{ Planted Area (ha) } \\
\cline { 2 - 4 } & 1988 & 2002 & 2008 \\
\hline Total & $\mathbf{4 3 . 2 3 3}$ & $\mathbf{3 6 . 9 1 6}$ & $\mathbf{3 9 . 9 5 1}$ \\
\hline Very Small & 4.912 & 2.652 & 2.109 \\
\hline Small & 6.170 & 3.863 & 3.156 \\
\hline Medium & 10.351 & 8.194 & 7.579 \\
\hline Medium Large & 7.578 & 7.370 & 7.616 \\
\hline Large & 5.425 & 6.501 & 7.411 \\
\hline Very Large & 8.797 & 8.335 & 12.080 \\
\hline
\end{tabular}

Table 6. Oasis Este Provincia of Mendoza. Intercensus evolution of Viticultural EAP by stratus (EAP).

\begin{tabular}{|l|r|r|r|}
\hline \multirow{2}{*}{ Stratus } & \multicolumn{3}{|c|}{ Viticultural EAP } \\
\cline { 2 - 4 } & 1988 & 2002 & 2008 \\
\hline Total & $\mathbf{6 . 3 0 0}$ & $\mathbf{4 . 8 3 0}$ & $\mathbf{4 . 2 5 6}$ \\
\hline Very Small & 3.131 & 2.095 & 1.707 \\
\hline Small & 1.268 & 1.005 & 899 \\
\hline Medium & 1.234 & 1.100 & 1.018 \\
\hline Medium Large & 397 & 396 & 379 \\
\hline Large & 198 & 176 & 176 \\
\hline Very Large & 72 & 58 & 77 \\
\hline
\end{tabular}

Table 7. Oasis Este Provincia of Mendoza. Intercensus evolution of the planted area in Viticultural EAP by stratus (ha).

\begin{tabular}{|l|r|r|r|}
\hline \multirow{2}{*}{ Stratus } & \multicolumn{3}{|c|}{ Planted Area (ha) } \\
\cline { 2 - 4 } & 1988 & 2002 & 2008 \\
\hline Total & $\mathbf{7 8 . 0 1 8}$ & $\mathbf{6 7 . 0 0 8}$ & $\mathbf{6 6 . 9 7 1}$ \\
\hline Very Small & 7.077 & 5.260 & 4.367 \\
\hline Small & 9.556 & 7.712 & 6.819 \\
\hline Medium & 19.938 & 17.785 & 16.528 \\
\hline Medium Large & 14.005 & 13.909 & 13.129 \\
\hline Large & 13.506 & 12.354 & 12.153 \\
\hline Very Large & 13.937 & 9.987 & 13.974 \\
\hline
\end{tabular}

recessive than those exposed at the provincial level. The Large farms exhibited a Regressive Countercyclical path down in frequency and extent with respect to the provincial average where they grew. The acreage rate of Medium ones is Very Regressive with respect to zonal average and the concentration of Very Large and Large units grew from $35 \%$ to $39 \%$.

\subsubsection{Valle de Uco}

A slight growth in the number of holdings is registered, unlike in the other zones. These global figures mask regressive processes in lower strata with the important expansion of the biggest, which show a countercyclical path dynamics, comparing with provincial averages all sizes are Less Recessive or have countercyclical dynamics.

The extension of these systems grew by $87 \%$, this expansive process did not reach the Small and Very Small, who lost participation (countercyclical recessive with respect to the area), but they lost fewer area than provincial averages Stratus (Less recessive). Medium and Medium
Table 8. Valle de Uco Provincia of Mendoza. Intercensus evolution of Viticultural EAP by stratus (EAP).

\begin{tabular}{|l|c|c|c|}
\hline \multirow{2}{*}{ Stratus } & \multicolumn{3}{|c|}{ Viticultural EAP } \\
\cline { 2 - 4 } & 1988 & 2002 & 2008 \\
\hline Total & $\mathbf{5 4 3}$ & $\mathbf{6 1 8}$ & $\mathbf{5 5 9}$ \\
\hline Very Small & 201 & 176 & 127 \\
\hline Small & 141 & 150 & 128 \\
\hline Medium & 108 & 128 & 131 \\
\hline Medium Large & 57 & 105 & 87 \\
\hline Large & 24 & 37 & 60 \\
\hline Very Large & 12 & 22 & 26 \\
\hline
\end{tabular}

Table 9. Valle de Uco Provincia of Mendoza. Intercensus evolution of the planted area in Viticultural EAP by stratus (ha).

\begin{tabular}{|l|r|r|r|}
\hline \multirow{2}{*}{ Stratus } & \multicolumn{3}{|c|}{ Planted Area (ha) } \\
\cline { 2 - 4 } & 1988 & 2002 & 2008 \\
\hline Total & $\mathbf{8 . 8 6 4}$ & $\mathbf{1 4 . 0 7 5}$ & $\mathbf{1 6 . 5 4 6}$ \\
\hline Very Small & 586 & 554 & 420 \\
\hline Small & 1.070 & 1.182 & 1.022 \\
\hline Medium & 1.719 & 2.110 & 2.109 \\
\hline Medium Large & 2.035 & 3.772 & 3.176 \\
\hline Large & 1.836 & 2.525 & 4.171 \\
\hline Very Large & 1.619 & 3.931 & 5.649 \\
\hline
\end{tabular}

Table 10. Oasis Sur Provincia of Mendoza. Intercensus evolution of Viticultural EAP by stratus (EAP).

\begin{tabular}{|l|r|r|r|}
\hline \multirow{2}{*}{ Stratus } & \multicolumn{3}{|c|}{ Viticultural EAP } \\
\cline { 2 - 4 } & 1988 & 2002 & 2008 \\
\hline Total & 4.418 & 2.319 & 1.630 \\
\hline Very Small & 2.409 & 1.236 & 809 \\
\hline Small & 1.180 & 628 & 438 \\
\hline Medium & 622 & 332 & 274 \\
\hline Medium Large & 143 & 74 & 67 \\
\hline Large & 47 & 28 & 28 \\
\hline Very Large & 17 & 21 & 14 \\
\hline
\end{tabular}

Large holdings have countercyclical surface dynamics in relation to average values of the stratus because they rose, while the rest declined and the elderly surface was more dynamic than the average of stratus, noting that the most significant growth in this group is located in this zone. Concentration in Large to Very Large farms increased from $39 \%$ to $59 \%$.

\subsubsection{Oasis Sur}

In Oasis Sur, only $37 \%$ of the holdings seen at the start of the analysis persist, the most important loss at zonal value. Very Small EAP retreated still more (Very Regressive). The rest were less recessive than the zone average.

All the strata of Oasis Sur have very regressive dynamics when compared with the provincial strata average; the large are Counter-Cyclical Regressive (Table 10). The rates of the areas have the same meaning as set forth in frequency properties as shown in Table 11. 
Table 11. Oasis Sur Provincia of Mendoza. Intercensus evolution of the planted area in Viticultural EAP by stratus (ha).

\begin{tabular}{|l|r|r|r|}
\hline Stratus & \multicolumn{3}{|c|}{ Ha Vitícolas y Mixto Vitícolas } \\
\hline & 1988 & 2002 & 2008 \\
\hline Total & 36.508 & 20.056 & 16.435 \\
\hline Very Small & 6.458 & 3.389 & 2.271 \\
\hline Small & 8.763 & 4.687 & 3.313 \\
\hline Medium & 9.546 & 5.017 & 4.218 \\
\hline Medium Large & 4.783 & 2.490 & 2.338 \\
\hline Large & 3.221 & 1.846 & 1.801 \\
\hline Very Large & 3.738 & 2.627 & 2.495 \\
\hline
\end{tabular}

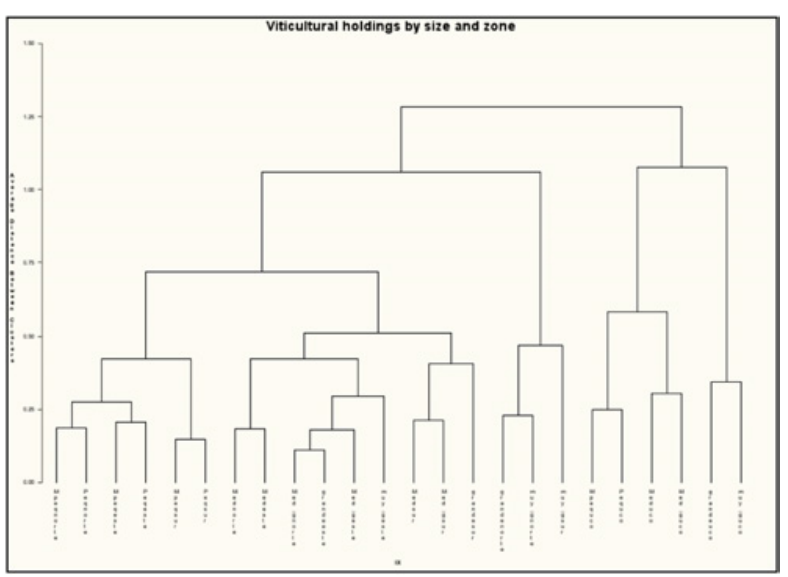

Figure 2. Viticultural EAP of Mendoza. Clustering Dendrogram by dynamic rates of stratus and zones.

\subsection{Comparing dynamic rates and clustering}

Each file in the data base (case) was formed by stratus and oasis; the selected variables to evaluate the dynamic were: 1) rate of growth or reduction of EAP of case/ rate of growth or reduction of EAP of zone 2) rate of growth or reduction of EAP of case/ rate of growth or reduction of EAP on the Stratus 3) Average rate of zone 4) Average rate of Stratus 5) Importance Frequency case. The relative changes in area were collinear and were excluded from the analysis. Four groups emerged as a result of the classification identifying various behaviors. These are described in Table 8. The clustering procedure is exposed in Fig. 2.

Figure 3 shows the distribution of cases according to the resulting clusters. Cluster 1) are holdings of zones with regressive behavior and each one shows Very Regressive or Regressive trajectories, farms Very Small to Medium Large sited in Oasis Norte, all ones in the Oasis Este and the Very Small to Large in Oasis Sur comprise this agglomeration. Cluster 2) is formed by holdings with trajectories slightly higher or lower than the zonal averages and stratus, Large and Very Large vineyards of Oasis Norte and Very Large ones in Oasis Sur were set in this group. Cluster 3) results of grouping cases of recessive dynamic of dynamic areas like Valle de Uco's smaller holdings. The fourth Cluster is composed by Very Dynamic forms in dynamic areas, formed by establishments Large and Very Large in the Valle de Uco.

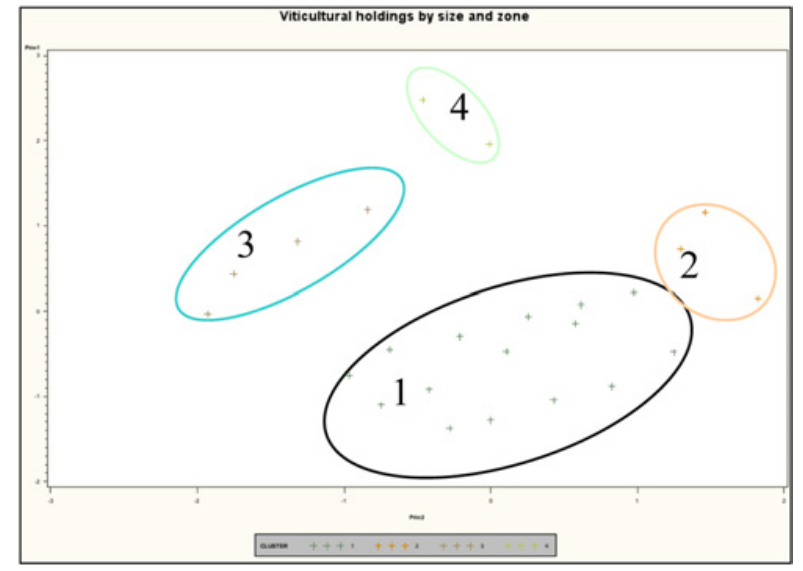

Figure 3. Viticultural EAP of Mendoza. Clustering procedure of sizes and zones by dynamic rates.

\section{Conclusions}

The variable farm size, assessed by the implanted area showed differential dynamics. It is a factor to be considered in the vulnerability analysis. It is clearly seen that the smaller the holding is, higher is their disappearance rate at the provincial level. This can be explained both by the lack of competitiveness inherent to its smallholder nature, and also to the proximity to urban areas - this group is the oldest and therefore the most "splitted"- and these units become attractive to real estate development. Analyzing the zonal peculiarities, in the Oasis Norte it is observed an increasing polarization process which reduces the number of the most Small and grow Large ones, these processes are carried out at different sectors of the Oasis; peri-urban agriculture yield land of the Small farms while new vineyards are allocated in the foothills of the southern sector and surrounding areas because of agro ecological potential and land structure that fit to larger management units. The two larger sizes changed from $33 \%$ concentration of the implanted area to $49 \%$. In this area not only the Large and Very Large units advanced, but also Medium Large, which is not observed in other areas of the Province.

The Oasis Este is the main wine region of Argentina. Although the regression processes are present, Small and Very Small units have reduced, but this rate is less acute than in neighboring Oasis Norte. This fact can be attributed to greater distances to Mendoza Metropolitan Area, which reduces the opportunity cost of land, as well as competition for other resources such as human. Unlike the previous area, it is not observed expansive processes in Large and Very Large holdings and the concentration of area of these grew only by $4 \%$.

This analysis has revealed behavioral differences in the Uco Valley in relation with the provincial values, different dynamics are attributed to both the recognition of their suitability for the wine production of higher ranges, as a low baseline, as the Valley was historically oriented towards the production of pome fruits, horticulture and forestry. However, inward differential phenomena are observed between Small and Large holdings, the first are not involved in the expansion process of the others, 
but they decreased at lower rates than the same in other zones. The growth was concentrated in larger farms with dimensions of Medium to Very Large. The concentration in units Large to Very Large shifted from 39\% to 59\%. Like the Oasis Norte, both processes were spatially separated, the Small ones render up the land to other uses, or were abandoned in traditional areas, and the others scattered on the foothills or located in old areas with other previous activities.

It is in the Oasis Sur where agricultural involution is more remarkable, only one-third of the registered units 20 years before remains. The Very Small vineyards of Oasis Sur constitute the most vulnerable group of all provincial vineyard agro ecosystems. The rest strata are Very recessive, almost all over Mendoza averages. The causes of this phenomenon are assigned as both economic and environmental, due to the high incidence of hail and frost. The demand of land for urban or touristic use is rising, since this activity has grown significantly.

This work is a quantitative first approach; it is a starting point for a qualitative analysis using appropriate tools to explore in an appropriate scale the meanings, logic or family trajectories, which provide better interpretation to this description and improve the explanatory power that by their nature the database of census is insufficient.

While several of the above phenomena are publicly recognized, this paper advances in assessing the magnitude and appreciation of peculiarities. The knowledge achieved here complements the work done in the trajectory analysis of social types.

This work is a result of the Agreement between CR Mendoza San Juan of INTA and the Dirección de Estadística e Investigaciones Económicas del Gobierno de Mendoza (DEIE). The cartography was designed by Ing. Agr. Federico Olmedo of EEA Mendoza INTA.

\section{References}

[1] C.T Michieli Antigua Historia de Cuyo. San Juan: Ansilta Editora P.99 (1994)

[2] R.A. Richard Jorba Poder, Economía y Espacio en Mendoza 1850-1900. Del comercio ganadero a la agroindustria vitivinícola Facultad de Filosofía y Letras. UNCuyo Mendoza (1998)

[3] D. Azpiazu, E. Basualdo El complejo vitivinícola argentino en los noventa: potencialidades y restricciones ed. D. Azpiazu and E. Basualdo, Buenos Aires: Facultad Latinoamericana de Ciencias Sociales, Sede Argentina. 203 p. (2001)

[4] M.E. Van den Bosch Un modelo de desarrollo sustentable para las áreas bajo riego de Ugarteche y El Carrizal. Departamento de Luján de Cuyo. Un aporte para el ordenamiento territorial rural, in Facultad de Filosofía y Letras Universidad Nacional de Cuyo Mendoza. p. 300 (2008)

[5] C. Csaki, Z. Lerman Land and Farm Structure in Poland, in Discussion Paper No. 10.01 The Hebrew University of Jerusalem (2001)

[6] C.C. Hinrichs, R. Welsh Agricul. \& Human Values 20: p. $125-141$ (2003)
[7] E. Archetti, K.A. Stolen, Explotación familiar y acumulación de capital en el campo argentino, ed. S. XXI Buenos Aires 229 (1975)

[8] E. Margiotta, R. Benencia,Introducción al estudio de la estructura agraria. La perspectiva sociológica UBA Buenos Aires. p. 20. (1995)

[9] E.D. Cittadini, J.C. Manchado, M. Mosciaro Area de Economía y Sociología Rural $n 82$ INTA Balcarce. p. 1-20 (1990)

[10] P. Tsakoumagkos Estudio sobre los pequeños productores agropecuarios y el desarrollo rural en la Argentina G. Secretaría Agricultura, Pesca y Alimentos, Editor (2008)

[11] K.Happe et al. J. of Econ. Behav. \& Org. 67 p. 431444 (2008)

[12] R.Welsh Agric Hum Values. 2009 (26) p. 21-28 (2009)

[13] A.Piorr et al. Environ. Sc. and Pol. p. 15. (2009)

[14] E. D. Cittadini, et al. Área de Economía y Sociología Rural $n 92$ INTA Balcarce p. 1-28 (1991)

[15] D. Slutzky VI Jornadas Interdisciplinarias de estudios agrarios y agroindustriales. Buenos Aires FCE UNBA (2009)

[16] T. Wołek IAMO Studies Series IAAE 2009 Minisymp. 49(2009): p. 1-22 (2009)

[17] M.E. Gudiño, B. Villegas de Lillo, Cuad. Geográf. 31p. 149-171 (2001)

[18] G.E. Reyes. Nómadas. Julio Diciembre(4): p.1 -23 (2001)

[19] E. Tapella Est. Sociol. $22 \mathbf{N}^{\circ}$ (66) (2004)

[20] T. Linck Rev.del ALASRU 3 p. 251-285. (2006)

[21] A.Y. Hoekstra Ecolog. Econ. 68(2009) p. 1963-1974 (2009)

[22] F. Rembold Land Reform Land Settlement and Cooperatives, P. Groppo, et al., Editors. FAO Rome (2003)

[23] M.Č. Istenič, D.K. Hočevar Neue Impulse in der Agrar- und Ernährungswirtschaft?! 18. Jahrestagung der Österreichischen Gesellschaft für Agrarökonomie (OGA) Wien OGA (2008)

[24] R. Romero-Calcerrada, G.L.W. Perry, Landsc. and Urban Plan. 66(2004): p.217-232 (2004)

[25] T. Glauben, H. Tietje, C. Weiss,. Jahrbuch fur Regionalwissenschaft,. 2006(26): p. 103-118 (2006)

[26] L. Zalazar, E. Pérez Romagnoli, Bol. Est. Geográf. 95(XXIX) p.132 (1996)

[27] M.E. Furlani, M.J. Gutiérrez Rev. THEOMAI Est. sobre Soc. Nat. y Des. 9 (2004)

[28] J.D. de Prada, et al. XLIII Reunión Anual de la Asociación Argentina de Economía Agraria Corrientes: AAEA. (2012)

[29] D.H. Wrenn, A. Sam, E.G. Irwin. Agric. \& Appl.Econ. Assoc. 2012 AAEA Annual Meeting Seattle Washington AAEA (2012)

[30] C. Reboratti Agric,, Soc. y Amb. Miradas y conflictos, C. Reboratti, Editor., FLACSO Maestría en Estudios Sociales Agrarios Buenos Aires. p. 162-180. (2011)

[31] C. Luchia Mundo Agrario. Rev. de Est. Rur. 5(9) (2004)

[32] G.R. Conway Agricult. Syst. 24(1987): p. 95-117 (1987) 
[33] C.S. Holling Ann.Rev. of Ecol. and Syst. 4(1973) p. $1-12(1973)$

[34] C.S. Holling, L.H. Gunderson, Panarchy understanding transformations in human and natural systems, L.H. Gunderson and C.S. Holling, Editors.. p. 25-50 (2002)

[35] M. Schouten, M. Van der Heide, W. Heijman 113 th EAAE Seminar "The Role of Knowledge,
Innovation and Human Capital in Multifunctional Agriculture and Territorial Rural Development" Belgrade, Republic of Serbia EAAE (2009)

[36] C. Folke et al. Ambio 31(5) p. 437-440 (2002)

[37] G.S. Cumming, G. Barnes Landsc. \&Urban Plann. 83(2007) p. 219-227 (2007)

[38] J.F.J. Hair et al. Multivariate Data Analysis., London Prentice Hall. 816. (2001) 